Available online on 15.02.2019 at http://jddtonline.info
O 2011-18, publisher and licensee JDDT, This is an Open Access article which permits unrestricted
non-commercial use, provided the original work is properly cited

Open $\odot$ Access

Mini Review

\title{
Application of Nanoparticles for Brain and Lung Cancer Therapeutics
}

\section{Xialin Chen}

State Key Laboratory of New-tech for Chinese Medicine Pharmaceutical Process, Jiangsu Kanion Pharmaceutical Co. Ltd., Lianyungang, 222001, China

\begin{abstract}
Nanotechnology is and will be the future of several fields and medicine is one of them. The use of nanoparticles in the treatment of psychotic and cancer problems is analyzed in this report. Psychotic treatment has been effective due to specific nanoparticles like haloperidol and RISP, and these combinations are linked with other nanoparticles to treat other diseases. Nanoparticles have extended applications with a high degree of effectiveness to treat cancer cells due to the quick delivery, and targeted process and the same is detailed in the review sheet. Oligonucleotides combined with nanoparticles have greater efficiencies.
\end{abstract}

Keywords: Nanotechnology, drug targeting, cancer treatment

Article Info: Received 13 Jan 2019; Review Completed 02 Feb 2019; Accepted 08 Feb 2019; Available online 15 Feb 2019

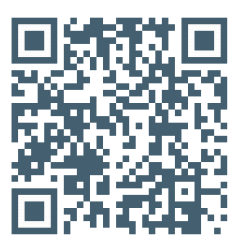

\section{Cite this article as:}

Chen X, Application of Nanoparticles for Brain and Lung Cancer Therapeutics, Journal of Drug Delivery and Therapeutics. 2019; 9(1-s):384-386 http://dx.doi.org/10.22270/jddt.v9i1-s.2337

\section{*Address for Correspondence:}

Xialin Chen, State Key Laboratory of New-tech for Chinese Medicine Pharmaceutical Process, Jiangsu Kanion Pharmaceutical Co. Ltd., Lianyungang, 222001, China

\section{Introduction}

Modern medicine uses nanoparticles for various drug delivery and treatment systems such as magnetic resonance imaging, cancer treatment, tumor treatment, and cell treatment ${ }^{1-9}$. Nanotechnology has allowed the researchers to experiment with different combinations of nanoparticles to apply the best to the biological devices and develop proper engineered materials to the patients. This review begins with an introduction on the need for nanoparticles followed by two different sections to explain the impact of nanoparticles in the treatment of tumor and lung cancer ${ }^{10-16}$.

\section{The need for nanoparticles}

Nanotechnology has gained widespread usage in the field of medicine. Nanoparticles have been used as a drug delivery material to deliver light, heat and other substances to the affected cells ${ }^{17-23}$. It is observed that nanoparticles are efficient than other drug delivery methods for serious health problems such as cancer since nanoparticles can directly penetrate to cancer-causing cells and control its activity to a greater extent ${ }^{24-27}$. The targeted delivery is the reason for the widespread use of nanoparticles. Further, they dissolve within the cell leaving no side effect but a long-term impact on the body.
There are varied combinations of nanomaterials out of which solid-lipid and the polymeric nanoparticles tend to achieve higher success rate due to the biocompatibility and the safety associated with it. The treatment methodology used for the tumor can be repeated for lung cancer, too.

\section{Impact of nanoparticles on brain problems}

There are two types of issues addressed in this section psychological and brain tumor. The modern society has shown a high prevalence of psychosis ${ }^{28-32}$. To control the mental problems, antipsychotic medications have now been recommended involving nanoparticles that will develop building blocks and ensure a slow release process. Haloperidol (HP) loaded nanoparticle is used to treat schizophrenia and blocks the D2 dopamine receptors. Further, the dendrimers are altered to be induced as nanoparticles. A popular antipsychotic drug is risperidone (RISP) which is required to treat schizophrenia. The process of antipsychotic delivery is not researched in depth. However, nanoparticle-based administration to the treatment of psychotic problems tends to enhance the life of the affected individual and prove biocompatibility $33-38$. 


\begin{tabular}{|c|c|c|c|}
\hline Drug Name & Nanoparticle Type & Materials & Ref \\
\hline Haloperidol & $\begin{array}{l}\text { Solid lipid } \\
\text { Polymer } \\
\text { Dendrimer }\end{array}$ & $\begin{array}{l}\text { Glyceryl Monostearate + Tween } 80 \\
\text { Poly- }- \text {-caprolactone + Polysorbate } 80 \\
\text { Polyamidoamine }\end{array}$ & $\begin{array}{l}\text { Yasir and Sara [2014] } \\
\text { Benvegnu et al. [2011] } \\
\text { Katare et al. [2015] }\end{array}$ \\
\hline Chlorpromazine & $\begin{array}{l}\text { Supramolecule } \\
\text { Polymer }\end{array}$ & $\begin{array}{l}\text { Calixarene } \\
\text { PLGA }\end{array}$ & $\begin{array}{l}\text { Qin et al. [2014] } \\
\text { Halayqa and Domanska [2014] }\end{array}$ \\
\hline Perphenazine & Polymer & PLGA & Halayqa and Domanska [2014] \\
\hline Promazine & Polymer & PLGA & Domańska and Halayqa [2014] \\
\hline Risperidone & $\begin{array}{l}\text { Solid lipid } \\
\text { Solid lipid/Polymeric Hydrogel } \\
\text { Solid lipid/Polymeric Inplant }\end{array}$ & $\begin{array}{l}\text { Compritol8 888ATO } \\
\text { Glyceryl Monostearate + Carbomer } 2001 \\
\text { Stearic acid/Glyceryl Monostearate + PLGA }\end{array}$ & $\begin{array}{l}\text { Silva et al. [2012b] } \\
\text { Silva et al. [2012a] } \\
\text { Dong et al. [2011] }\end{array}$ \\
\hline Paliperidone & $\begin{array}{l}\text { Solid lipid } \\
\text { Solid lipid } \\
\text { Solid lipid }\end{array}$ & $\begin{array}{l}\text { Capmul } 8 \text { GMS-50K + sodium deoxycholate } \\
\text { Capmul@ GMS-50K + Gelucire@ } 50 / 13 \\
\text { Stearic acid + Gelucire } 80 / 13\end{array}$ & $\begin{array}{l}\text { Kumar and Randhawa [2013] } \\
\text { Kumar and Randhawa [2014] } \\
\text { Kumar and Randhawa [2015] }\end{array}$ \\
\hline Quetiapine & $\begin{array}{l}\text { Solid lipid } \\
\text { Polymer } \\
\text { Solid lipid/Polymeric Hydrogel }\end{array}$ & $\begin{array}{l}\text { Glyceryl Trimyristate + Poloxamer } 188 \& 407 \\
\text { Chitosan + Tripolyphosphate } \\
\text { Glycerol monostearate + Poloxamer } 188 \& 407\end{array}$ & $\begin{array}{l}\text { Aboti et al. [2014] } \\
\text { Shah et al. [2016] } \\
\text { Li et al. [2015] }\end{array}$ \\
\hline Clozapine & $\begin{array}{l}\text { Polymer } \\
\text { Polymer }\end{array}$ & $\begin{array}{l}\text { Poly-L-glutamic acid + Poly-L-lysine } \\
\text { Poly-(s-caprolactone) + Polysorbate 80/PEG/CS }\end{array}$ & $\begin{array}{l}\text { Lukasiewicz et al. [2016] } \\
\text { Vieira et al. [2016] }\end{array}$ \\
\hline Olanzapine & $\begin{array}{l}\text { Polymer } \\
\text { Polymer }\end{array}$ & $\begin{array}{l}\text { PLGA } \\
\text { Chitosan + Tripolyphosphate }\end{array}$ & $\begin{array}{l}\text { Seju et al. [2011] } \\
\text { Baltzley et al. [2014] }\end{array}$ \\
\hline $\begin{array}{l}\text { Aripiprazole } \\
\text { Sulpiride }\end{array}$ & $\begin{array}{l}\text { Polymer } \\
\text { Solid lipid }\end{array}$ & $\begin{array}{l}\text { Poly(caprolactone) + Poloxamer } 188 \& 407 \\
\text { Dynasan/Stearic acid + Tween } 80\end{array}$ & $\begin{array}{l}\text { Sawant et al. [2016] } \\
\text { lbrahim et al. [2014] }\end{array}$ \\
\hline
\end{tabular}

For the brain tumor, it is a severe case though nanoparticles are available in abundance in the market. The problem is the absence of a substance that can control brain tumor-like glioblastoma at an earlier stage. Nanoparticle plays a role in such situations. Further, the brain tumor is treated with chemotherapy that has high cytotoxicity and nanoparticles tend to eliminate the blood-brain barriers ${ }^{29}$. In vivo and in vitro are the nanomaterials where nanoparticles have the abilities to link and bond with macromolecules and ease the circulation ${ }^{29}$.

Gold nanoparticles have been very useful to perform brain targeting followed by drug delivery. The electrons are conducted on the metal surface, and there is an excitation by light. Serine-arginine-leucine (SRL) modified dendrimers are found to have higher rates of transfusion, and the toxicity level is hugely less. The problem faced in the treatment of brain tumor is the specificity and targeting 39,40 . Glioblastoma multiforme, a form of brain tumor, is aggressive and makes it difficult for the procedure to turn effective. Fibrin binding peptide can be induced to treat this case ${ }^{29}$.

Polymeric, lipid and magnetic and microbubble nanoparticles have been useful in the treatment of brain tumor. They have addressed the neoplasm groups and reduced the toxicity with the application of nanoparticles. These generate proteins needed to control the impact of tumor and enhance the success rate of treatment.

\section{Impact of nanoparticles on lung cancer}

Human cancer is developed due to the excessive expression of Bcl-2 which is an anti-apoptotic gene. This expression has been controlled with the help of antisense oligonucleotides (ASOs) therapy ${ }^{21,22}$. However, there have been problems in the binding affinity and immunity of oligonucleotide. This has led to the demand of lipid nanoparticles which can increase the overall nuclease stability and the circulation time of such oligonucleotides $8,21,22$.

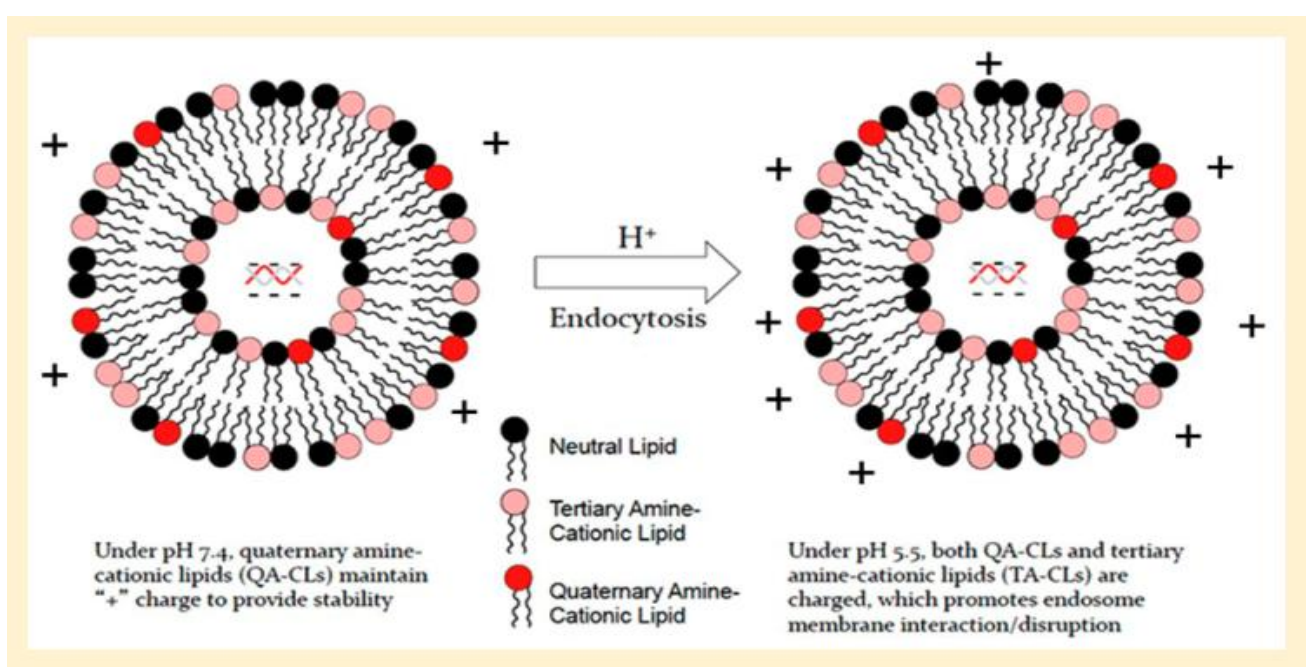

It is true that gapmer design can downregulate the presence of cancer and improve the binding affinity. So far, the treatment of lung cancer has shown positive results with LNP formulation as the in vitro and in vivo activities are high, and there is considerable stability which can improve the usefulness of the therapy ${ }^{21,22}$. While antisense oligonucleotide combined with lipid nanoparticles is called an effective therapy, quaternary amine-tertiary amine cationic lipid combination ensures an efficient and costeffective treatment, too. 
The latter works in both in vitro and in vivo gene regulation. The nanoparticles slowly invade the affected region and alter the surface and charge it to enhance the quality delivery of the oligonucleotides. miR-21 plays an essential role in regulating the propagation of tumor and cancer. QTsome nanoparticles are ideal for inducing strong dosage of the therapy without affecting the sensitivity and increasing the invasion pace ${ }^{10,11,21-23 .}$

\section{Conclusion}

The nanoparticle powered treatment for tumor and cancer in addition to the psychotic analysis is the most effective and sustainable therapy which can change the way other diseases are treated. Though varied combinations of nanoparticles are chosen, this still serves as a suitable therapy mode due to its suitability and biocompatibility, and there is no side effect, unlike conventional chemotherapy. As a result, it is possible to expect faster results with the targeted delivery of therapy.

\section{References}

1. Qiao, H., et al. Redox-triggered mitoxantrone prodrug micelles for overcoming multidrug-resistant breast cancer. Journal of drug targeting 26, 75-85 (2018).

2. Kang, C., Qin, J., Osei, W. \& Hu, K. Regulation of protein kinase Cepsilon and its age-dependence. Biochemical and Biophysical Research Communications 482, 1201-1206 (2017).

3. Sun, Y., et al. RGD Peptide-Based Target Drug Delivery of Doxorubicin Nanomedicine. Drug development research $\mathbf{7 8}$, 283-291 (2017)

4. Kang, C. \& Hu, K. Role of caveolin-3 in adenosine-induced increase in mitochondrial PKCE. The FASEB Journal 27, 1191.1197-1191.1197 (2013).

5. Cheng, X. \& Lee, R.J. The role of helper lipids in lipid nanoparticles (LNPs) designed for oligonucleotide delivery. Adv Drug Deliv Rev 99, 129-137 (2016).

6. Sun, Y. \& Kang, C. Self-Assembly of Peptides into Hydrogel. Journal of Organic \& Inorganic Chemistry 2, 5 (2016).

7. Yao, Z., Sun, Y. \& Kang, C. Structure and self-assembly of multicolored Naphthalene Diimides Semiconductor. Nano LIFE 6, 1642007 (2016).

8. Cheng, X., et al. T7 Peptide-Conjugated Lipid Nanoparticles for Dual Modulation of Bcl-2 and Akt-1 in Lung and Cervical Carcinomas. Molecular pharmaceutics 15, 4722-4732 (2018).

9. Zhong, X., Sun, Y., Kang, C. \& Wan, G. The theory of dielectrophoresis and its applications on medical and materials research. European Journal of BioMedical Research 2, 7-11 (2017).

10. Kang, C. \& Hu, K. Modulation of the two-pore domain potassium channel TASK-1 by caveolin-3. The FASEB Journal 29, 845.814 (2015).

11. Davis, M.E., Chen, Z.G. \& Shin, D.M. Nanoparticle therapeutics: an emerging treatment modality for cancer. Nat Rev Drug Discov 7, 771-782 (2008).

12. Kang, C., Sun, Y., Wang, M. \& Cheng, X. Nanosized camptothecin conjugates for single and combined drug delivery. European Journal of BioMedical Research 2, 8-14 (2016).

13. Qiao, H., et al. Orally delivered polycurcumin responsive to bacterial reduction for targeted therapy of inflammatory bowel disease. Drug Delivery 24, 233-242 (2017).

14. Liu, F., Sun, Y., Kang, C. \& Zhu, H. Pegylated Drug Delivery Systems: From Design to Biomedical Applications. Nano LIFE 6 1642002 (2016).

15. Sun, Y., Kang, C., Yao, Z., Liu, F. \& Zhou, Y. Peptide-Based Ligand for Active Delivery of Liposomal Doxorubicin. Nano Life 6, 1642004 (2016)

16. Yeh, C.Y., Hsiao, J.K., Wang, Y.P., Lan, C.H. \& Wu, H.C. Peptideconjugated nanoparticles for targeted imaging and therapy of prostate cancer. Biomaterials 99, 1-15 (2016).

17. Li, Q., et al. Identification by shape-based virtual screening and evaluation of new tyrosinase inhibitors. PeerJ 6, e4206 (2018).

18. Chen, Y., et al. Identification of 4-aminoquinoline core for the design of new cholinesterase inhibitors. PeerJ 4, e2140 (2016).
19. Kang, C. \& Hu, K. Impact of hypoxia in the expression and regulation of the TASK-1 potassium channel in cardiac myocytes. The FASEB Journal 30, lb598-lb598 (2016).

20. Kang, C. Ion channels, protein kinase $C$ and caveolae in cardioprotection, (The Ohio State University, 2015).

21. Yung, B.C., et al. Lipid nanoparticles composed of quaternary amine-tertiary amine cationic lipid combination (QTsome) for therapeutic delivery of AntimiR-21 for lung cancer. Molecular pharmaceutics 13, 653-662 (2016).

22. Cheng, X., et al. Lipid Nanoparticles Loaded with an Antisense Oligonucleotide Gapmer Against Bcl-2 for Treatment of Lung Cancer. Pharmaceutical research 34, 310-320 (2017).

23. Fan, S. \& Chi, W. Methods for genome-wide DNA methylation analysis in human cancer. Brief Funct Genomics 15, 432-442 (2016).

24. Peng, J., et al. Enhanced Liver Regeneration After Partial Hepatectomy in Sterol Regulatory Element-Binding Protein (SREBP)-1c-Null Mice is Associated with Increased Hepatocellular Cholesterol Availability. Cellular Physiology and Biochemistry 47, 784-799 (2018).

25. Yang, Z., et al. Functional exosome-mimic for delivery of siRNA to cancer: in vitro and in vivo evaluation. Journal of Controlled Release 243, 160-171 (2016).

26. Kang, C., Hernandez, V.A. \& Hu, K. Functional interaction of the two-pore domain potassium channel TASK-1 and caveolin-3. Biochimica et Biophysica Acta (BBA)-Molecular Cell Research 1864, 1537-1544 (2017).

27. Waller, A.P., et al. GLUT12 functions as a basal and insulinindependent glucose transporter in the heart. Biochimica et Biophysica Acta (BBA)-Molecular Basis of Disease 1832, 121127 (2013).

28. Sun, Y., Kang, C., Liu, F. \& Song, L. Delivery of antipsychotics with nanoparticles. Drug Development Research 77, 393-399 (2016).

29. Kang, C., et al. Delivery of nanoparticles for treatment of brain tumor. Current Drug Metabolism 17, 745-754 (2016).

30. Xue, X., et al. Discovery of novel inhibitors disrupting HIF$1 \alpha$ /von Hippel-Lindau interaction through shape-based screening and cascade docking. PeerJ 4, e2757 (2016).

31. Hersch, S.J., et al. Divergent protein motifs direct elongation factor P-mediated translational regulation in Salmonella enterica and Escherichia coli. MBio 4, e00180-00113 (2013).

32. Shuhong, X., et al. Dynamic expression of AQP4 in early stageof ischemia/reperfusion rats and cerebral edema. Chinese Pharmacological Bulletin 32, 1433-1441 (2016).

33. Duan, Y., et al. Bioactivity evaluation-based ultra highperformance liquid chromatography coupled with electrospray ionization tandem quadrupole-time-of-flight mass spectrometry and novel distinction of multi-subchemome compatibility recognition strategy with Astragali Radix-Fructus Corni herb-pair as a case study. J Pharm Biomed Anal 129, 514534 (2016).

34. Sun, Y., et al. Co-delivery of dual-drugs with nanoparticle to overcome multidrug resistance. European Journal of BioMedical Research 2, 12-18 (2016).

35. Ai, R., et al. Comprehensive epigenetic landscape of rheumatoid arthritis fibroblast-like synoviocytes. Nat Commun 9, 1921 (2018).

36. Fan, S., et al. Computationally expanding infinium HumanMethylation450 BeadChip array data to reveal distinct DNA methylation patterns of rheumatoid arthritis. Bioinformatics 32, 1773-1778 (2016).

37. Liu, F., Sun, Y. \& Kang, C. Controlling Amphiphilic Functional Block Copolymers' Self-Assembly: From Structure to Size. (2016).

38. Song, L., et al. Crocetin inhibits lipopolysaccharide-induced inflammatory response in human umbilical vein endothelial cells. Cellular Physiology and Biochemistry 40, 443-452 (2016).

39. Kang, C., Qin, J., Osei, W. \& Hu, K. Age-dependent Mitochondrial Targeting Of Protein Kinase $\mathrm{C}$ Epsilon In Cardioprotection. The FASEB Journal (2017).

40. Han, R., Sun, Y., Kang, C., Sun, H. \& Wei, W. Amphiphilic dendritic nanomicelle-mediated co-delivery of 5-fluorouracil and doxorubicin for enhanced therapeutic efficacy. Journal of Drug Targeting 25, 140-148 (2017). 